\title{
Predictive role of HER2-status on the effectiveness of endocrine adjuvant treatment in postmenopausal breast cancer patients: a population-based cohort study
}

\author{
Aglaia Schiza $^{1,2}$ (D) Davide Mauri ${ }^{3} \cdot$ Irma Fredriksson $^{4,5} \cdot$ Anna-Karin Wennstig $^{6,7} \cdot$ Antonios Valachis $^{1,8}$
}

Received: 30 September 2020 / Accepted: 13 November 2020 / Published online: 30 November 2020

(c) The Author(s) 2020

\begin{abstract}
Purpose There are conflicting results on the potential role of HER2-status on the efficacy of aromatase inhibitors (AIs) and tamoxifen (TAM) in patients with hormone receptor (HR)-positive breast cancer (BC). The purpose of this population-based cohort study was to investigate the potential benefit of AIs compared to TAM as adjuvant therapy in postmenopausal BC patients by HER2-status in the era of modern therapy with HER2-blockade.

Methods A population-based cohort study was performed including all postmenopausal women diagnosed with HR-positive BC without distant metastasis between 2007 and 2012 in three healthcare regions in Sweden. We analyzed the breast cancerspecific survival (BCSS) and overall survival (OS) in two distinct cohorts (HER2-negative, HER2-positive) based on the type of endocrine therapy (ET) used. A propensity score matching was performed separately in the HER2-negative and HER2-positive cohorts, respectively.

Results After propensity score matching, 4368 patients with HER2-negative and 214 patients with HER2-positive BC were available for analysis. In the HER2-negative cohort, an improved BCSS [Hazard Ratio (HR): 0.51; 95\% confidence interval (CI): $0.34-0.77, p$ value $<0.001]$ and a trend toward improved OS (HR: 0.66; 95\% CI: $0.41-1.08, p$ value $=0.093$ ) in favor of AI-based therapy was observed. In the HER2-positive cohort, no statistically significant difference between AI-based ET and TAM was found in terms of either BCSS or OS, although the direction of HR was similar as in the HER2-negative cohort (HR for BCSS: 0.84; 95\% CI: 0.14-5.04, $p=0.849$; HR for OS: 0.62 ; 95\% CI: $0.10-3.38, p=0.345$ ).

Conclusion Our study results, based on propensity-matched cohorts, did not support any predictive value of HER2-status on endocrine therapy in postmenopausal BC patients. AI-based ET remains the treatment of choice for postmenopausal BC patients with HR-positive disease in the modern era of HER2-directed therapy irrespective of HER2-status.
\end{abstract}

Keywords Breast cancer $\cdot$ HER2-status $\cdot$ Hormone receptor-positive $\cdot$ Endocrine treatment $\cdot$ Adjuvant $\cdot$ Postmenopausal

Aglaia Schiza

aglaia.schiza@igp.uu.se

Anna-Karin Wennstig

anakinwen@gmail.com

Antonios Valachis

antonios.valachis@oru.se

1 Science for Life Laboratory, Department of Immunology, Genetics and Pathology, Uppsala University, Dag Hammarskjoldsvag 20, 75185 Uppsala, Sweden

2 Department of Oncology, Uppsala University Hospital, 75185 Uppsala, Sweden

3 Medical Oncology, University Hospital of Ioannina, Ioannina, Greece
4 Department of Molecular Medicine and Surgery, Karolinska Institutet, Stockholm, Sweden

5 Department of Breast and Endocrine Surgery, Karolinska University Hospital Solna, Stockholm, Sweden

6 Department of Surgical and Perioperative Science, Umeå University, 90185 Surgery, Umeå, Sweden

7 Department of Oncology, Sundsvall Hospital, 85186 Sundsvall, Sweden

8 Department of Oncology, Faculty of Medicine and Health, Örebro University, SE 70182 Örebro, Sweden 


$\begin{array}{ll}\text { Abbreviations } \\ \text { AIs } & \text { Aromatase inhibitors } \\ \text { BC } & \text { Breast cancer } \\ \text { BCSS } & \text { Breast cancer-specific survival } \\ \text { CCI } & \text { Charlson Comorbidity Index } \\ \text { ER } & \text { Estrogen receptor } \\ \text { ET } & \text { Endocrine therapy } \\ \text { HER2 } & \text { Human epidermal growth factor receptor 2 } \\ \text { HR } & \text { Hormone receptor } \\ \text { IHC } & \text { Immunohistochemistry analysis } \\ \text { IQR } & \text { Interquartile rate } \\ \text { OFS } & \text { Ovarian function suppression } \\ \text { PgR } & \text { Progesterone receptor } \\ \text { PS } & \text { Propensity score } \\ \text { PSM } & \text { Propensity score matching } \\ \text { SD } & \text { Standardized differences } \\ \text { TAM } & \text { Tamoxifen } \\ \text { OS } & \text { Overall survival }\end{array}$

\section{Introduction}

Breast cancer (BC) is a heterogeneous disease composed of various biologic subtypes with distinct behavior. Hormone receptor (HR)-positive [estrogen (ER) and/or progesterone (PgR) receptor-positive] BC comprises the most common type of BC, whereas amplification or overexpression of the human epidermal growth factor receptor 2 (HER2) oncogene is present in approximately $20 \%$ of invasive $\mathrm{BC}$, half of which also express HR [1].

The cornerstone of adjuvant treatment in HR-positive $\mathrm{BC}$ is the endocrine therapy (ET) which has resulted in improved survival $[2,3]$. For postmenopausal patients with HR-positive BC, both aromatase inhibitors (AIs) and tamoxifen (TAM) are valid treatment options but AIs have demonstrated superior efficacy compared to TAM [4]. In patients with HER2-positive invasive BC, HER2-directed therapy has altered the natural history of this aggressive subtype resulting in improved survival in all treatment settings [5, 6]. Patients with $\mathrm{HR}+/ \mathrm{HER} 2+\mathrm{BC}$ are treated with both $\mathrm{ET}$ and HER2-directed therapy in adjuvant setting.

A complex molecular bi-directional crosstalk between HR and HER2 receptor pathways has been observed. In fact, in vitro studies have identified different mechanisms of resistance to both TAM and AIs mediated by the HR/ HER 2 crosstalk [7, 8]. In addition, clinical evidence supports the preclinical observations since an inverse relationship between HER2 overexpression and response to ET has been observed in different treatment settings [9-12].

Considering the different resistance mechanisms that are mediated by the HR/HER2 crosstalk for AIs and TAM, one could argue that there might be clinically significant differences on the efficacy of AIs and TAM, respectively, depending on the treatment sequence in HER $2+\mathrm{BC}$. This hypothesis is not supported by the results of the EBCTCG meta-analysis comparing the efficacy of AIs versus TAM in postmenopausal women where AIs proved to be more effective irrespective of HER2-status [3]. However, more than $70 \%$ of patients in this meta-analysis had an "unknown" HER2-status and most of the patients were not treated with HER2-directed therapy, thus jeopardizing the generalizability of the results. In a recent meta-analysis of three adjuvant randomized trials with postmenopausal early-stage BC, Bartlett et al. [13] showed that patients with HR+/HER2 - BC benefited more from upfront $\mathrm{AI}$ compared to TAM in the adjuvant setting, whereas upfront $\mathrm{AI}$ in $\mathrm{HR}+/ \mathrm{HER} 2+\mathrm{BC}$ did not seem to provide any additional benefit compared to TAM. Though the meta-analysis of Bartlett overcame the limitation of "unknown" HER2-status through centrally confirmed HER2 analysis, most of the patients did not receive HER2-directed therapy. Dackus et al. provided data from a population-based cohort study indicating that postmenopausal patients with early-stage HR+/HER2 + BC may experience a small but, non-significant AI benefit. However, nearly $30 \%$ of the patients included in the analysis received no HER2-directed therapy [14].

Thus, conflicting clinical evidence about the potential impact of HER2-status on the efficacy of AIs compared to TAM do exist, whereas the inconsistencies in the treatment strategies regarding HER2-directed therapy among the current studies influence the generalizability of the results in the modern era. The aim of this population-based cohort study was to investigate whether the magnitude of potential benefit of AIs compared to TAM as adjuvant therapy in postmenopausal BC patients was different based on HER2-status in the modern era of HER2-directed therapy.

\section{Methods}

\section{Study design and data sources}

We performed a population-based cohort study using the $\mathrm{BCBaSe}$ database. $\mathrm{BCBaSe}$ is a research database consisting of the data linkage of The Regional Breast Cancer Quality Registries of the Uppsala/Örebro, Stockholm-Gotland and Northern regions of Sweden, the National Patient Register (information on hospital admission dates and diagnosis of diseases), the Swedish Cancer Register, the Swedish Cause of Death Register, the Swedish Prescribed Drug Register, all held by the National Board of Health and Welfare, and the Longitudinal Integration Database for Health Insurance and Labour Market Studies (LISA) and the Total Population Register, managed by Statistics Sweden. Information from these registers is linked using the ten-digit personal identifier 
numbers assigned for all citizens registered in Sweden. A detailed description of $\mathrm{BCBaSe}$ is presented elsewhere [14].

The datasets analyzed during the current study are available from the corresponding author on reasonable request.

\section{Identification of study cohort}

Within the BCBaSe, we identified all postmenopausal women residing in the Uppsala/Örebro, Stockholm-Gotland, and Northern health care regions of Sweden who were diagnosed with HR-positive invasive BC (regardless of HER2-status) without distant metastasis between January 1, 2007, and December 31, 2012. We excluded patients with unknown HER2-status, patients without ET registered, as well as patients with HER2-positive BC who did not receive trastuzumab as a part of neo-/adjuvant therapy. The type of ET was collected based on the planned treatment according to physicians' prescriptions. Nearly all patients were planned to receive 5 years endocrine treatment since extended endocrine therapy was not recommended by the Swedish National Guidelines during the study period.

During the study period ovarian function suppression (OFS) was an uncommon treatment choice for breast cancer patients as it was not recommended by the Swedish national guidelines. In any case, premenopausal patients who had addition of OFS to ET between 2007 and 2012 were not included in our study cohort. Since HER2-targeted adjuvant treatment became standard after 2005, only data after 2007 and later on were used to in the present study to reduce eventual treatment bias since HER2-targeted treatment were not uniformly available before that time.

\section{Definitions}

HR-positive $\mathrm{BC}$ was defined as estrogen receptor $\geq 10 \%$ and/ or progesterone receptor $\geq 10 \%$ according to the Swedish National Treatment Guidelines on BC. HER2 was defined as positive if HER 2 was categorized as $3+$ by immunohistochemistry analysis (IHC) or in IHC 2+ with amplification of the HER2 gene verified through situ hybridization.

The Charlson Comorbidity Index (CCI) was used to categorize patients according to the presence of co-morbidities.

The patients treated with ET were categorized as: TAMtreated when patients received only TAM; AI-based treated when the patients received AI only or sequential treatment with $\mathrm{AI}$ and TAM in any sequence.

\section{Outcomes of interest}

The outcomes of interest were breast cancer-specific survival (BCSS) defined as the time from $\mathrm{BC}$ diagnosis to death due to $\mathrm{BC}$, and overall survival (OS) defined as the time from
$\mathrm{BC}$ diagnosis to death due to any cause, in the two distinct cohorts (HER2-negative and HER2-positive cohorts).

\section{Statistical analysis}

The continuous variables were expressed by median and interquartile rate (IQR), whereas the categorical variables were expressed by number and percentage of patients in each category.

The Chi-square test was used for the bivariate analyses between type of endocrine treatment (TAM vs. AI-based) and patient- or tumor characteristics within two separate cohorts based on HER2-status.

To minimize the potential effect of confounding factors on the choice of ET, we used a propensity score matching (PSM) approach separately for the HER2-positive and HER2-negative cohorts to create more balanced ET groups. The propensity score (PS) was estimated using multivariate logistic regression model with the type of ET as dependent variables and the variables with statistically significant difference $(P$ value $<0.05)$ between the ET groups in the bivariate analyses as covariates. The variables with $>10 \%$ missing values were excluded from the models to maintain a good level of matching since the analyses were performed using the complete case approach. The following variables were included as covariates: age, type of surgery, histology, anatomic stage, PgR-status, CCI, and chemotherapy use.

A 1:1 PSM was performed using the nearest-neighbor matching method without replacement and a caliper width of 0.1. Post-match comparison between ET group and patientor tumor characteristics was performed using the standardized differences (SD). A SD below 0.1 was reliable enough to provide well-balanced characteristics after matching.

The analysis of time-to-event (BCSS, OS) outcomes among the PS-matched cases was performed by the Kaplan-Meier method and tested by log-rank test. Cox proportional hazards regression models were used to investigate whether there is an independent association between type of ET and BCSS or OS adjusting for variables associated with BCSS or OS, respectively (with a $P$ value $<0.05$ ) according to univariate Cox analyses.

All statistical analyses were performed using the Statistical Package for the Social Sciences (SPSS) (version 24.0; SPSS, Inc., Chicago, IL, USA), and $p<0.05$ were considered statistically significant. 


\section{Results}

\section{Study cohort}

From a total of 15,815 patients in $\mathrm{BCBaSe}, 10,225$ were eligible for the study cohort after applying the inclusion and exclusion criteria (Fig. 1). These patients were divided into a HER2-negative cohort $(n=9543)$ and a HER2-positive cohort $(n=682)$. After propensity score matching, 4368 patients in the HER2-negative cohort and 214 patients in the HER2-positive cohort remained available for analyses.

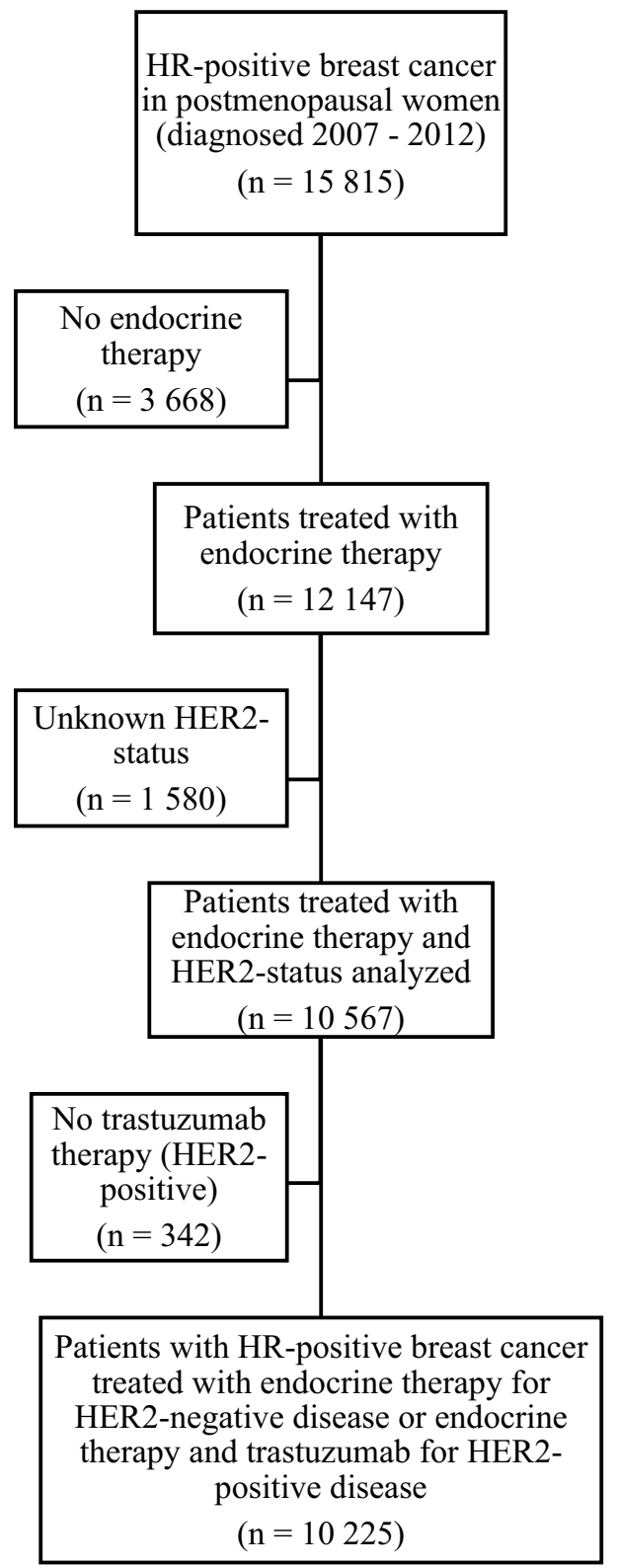

Fig. 1 Flowchart diagram of study cohort selection
The median follow-up was 44 months in the HER2-negative cohort (IQR: 33) and 42 months in the HER2-positive cohort (IQR: 32).

\section{Baseline characteristics}

Data on patient-, tumor and treatment characteristics in the HER2-negative cohort before and after matching are shown in Table 1. Before matching, AI-based ET was associated with more advanced age and negative prognostic factors as advanced stage, PgR-negative disease, grade III disease, and with more extensive adjuvant treatment (chemotherapy and radiotherapy). After propensity matching, age and use of radiotherapy remained statistically significantly associated with AI-based ET, but not the other above-mentioned variables.

Characteristics in HER2-positive cohort before and after matching are shown in Table 2. Before matching, AI-based ET was associated with more advanced age and stage. After propensity score matching no statistically significant differences in patient or treatment characteristics between the two groups were observed.

\section{Breast cancer-specific survival}

In the HER2-negative cohort, AI-based ET was associated with improved BCSS compared to TAM in the univariate Cox regression analysis (HR: 0.51; 95\% CI: 0.34-0.77, $p<0.001$; Fig. 2a).

Multivariate Cox regression for BCSS (adjusted for age, stage, histology, PgR-status, chemotherapy, radiotherapy, type of surgery, CCI, civil-status) showed a similar improvement in BCSS in favor of AI-based ET as in the univariate analysis (HR: 0.54 ; 95\% CI: 0.31-0.93, $p=0.032$ ).

In the HER2-positive cohort, AI-based ET was not associated with improved BCSS compared to TAM in the univariate Cox regression analysis (HR: 0.84; 95\% CI: 0.14-5.04), $p=0.849$; Fig. 2b). Neither did the multivariate Cox regression for BCSS show any statistically significant improved BCSS [HR: 0.90 (95\% CI: 0.15-5.45, $p=0.422$ )].

\section{Overall survival}

In the HER2-negative cohort, no statistically significant difference in OS between AI-based ET and TAM was observed in the univariate Cox regression analysis (HR: 0.89; 95\% CI $0.73-1.10, p=0.290$; Fig. 3a). In multivariate Cox regression analysis (adjusted for age, stage, histology, PgRstatus, chemotherapy, radiotherapy, type of surgery, CCI, civil-status education level, household income) we find a numerically but statistically non-significant improvement in OS in favor of AI-based ET (HR: 0.66; 95\% CI: 0.41-1.08, $p=0.093$ ). 
Table 1 Patient-, tumor and treatment characteristics in unmatched and propensity-matched patients with HER2-negative breast cancer

\begin{tabular}{|c|c|c|c|c|c|c|}
\hline \multirow[t]{2}{*}{ Characteristics } & \multicolumn{3}{|c|}{ Before matching } & \multicolumn{3}{|c|}{ After matching } \\
\hline & $\begin{array}{l}\text { Tamoxifen } \\
(n=4680)\end{array}$ & AI-based $(n=4863)$ & $P$ value & $\begin{array}{l}\text { Tamoxifen } \\
(n=2184)\end{array}$ & AI-based $(n=2184)$ & $P$ value \\
\hline $\begin{array}{l}\text { Age } \\
\leq 60 \\
61-65 \\
66-70 \\
71-75 \\
>75\end{array}$ & $\begin{array}{l}1218(26.0) \\
1092(23.3) \\
950(20.3) \\
586(12.5) \\
834(17.8)\end{array}$ & $\begin{array}{l}1131(23.3) \\
1069(22.0) \\
954(19.6) \\
673(13.8) \\
1036(21.3)\end{array}$ & $<0.001$ & $\begin{array}{l}608(27.8) \\
479(21.9) \\
328(15.0) \\
266(12.2) \\
503(23.0)\end{array}$ & $\begin{array}{l}503(23.0) \\
503(23.0) \\
458(21.0) \\
297(13.6) \\
423(19.4)\end{array}$ & $<0.001$ \\
\hline $\begin{array}{l}\text { Detection method } \\
\text { Screening } \\
\text { Clinically detected } \\
\text { Missing }\end{array}$ & $\begin{array}{l}2638(56.4) \\
1177(25.1) \\
865(18.5)\end{array}$ & $\begin{array}{l}2207(45.4) \\
1375(28.3) \\
1281(26.3)\end{array}$ & $<0.001$ & NA & NA & NA \\
\hline $\begin{array}{l}\text { Type of surgery } \\
\text { Breast conserving } \\
\text { Mastectomy }\end{array}$ & $\begin{array}{l}3335(71.3) \\
1345(28.7)\end{array}$ & $\begin{array}{l}2446(50.3) \\
2417(49.7)\end{array}$ & $<0.001$ & $\begin{array}{l}1307(59.8) \\
877(40.2)\end{array}$ & $\begin{array}{l}1376(63.0) \\
808(37.0)\end{array}$ & 0.032 \\
\hline $\begin{array}{l}\text { Histology } \\
\text { Ductal or mixed } \\
\text { Lobular } \\
\text { Other } \\
\text { Missing }\end{array}$ & $\begin{array}{l}3875(82.8) \\
489(10.4) \\
298(6.4) \\
18(0.4)\end{array}$ & $\begin{array}{l}4243(87.3) \\
516(10.6) \\
87(1.8) \\
17(0.3)\end{array}$ & $<0.001$ & $\begin{array}{l}1780(81.5) \\
90(4.1) \\
314(14.4) \\
0(0)\end{array}$ & $\begin{array}{l}1894(86.7) \\
59(2.7) \\
231(10.6) \\
0(0)\end{array}$ & $<0.001$ \\
\hline $\begin{array}{l}\text { Stage } \\
\text { I } \\
\text { II } \\
\text { III } \\
\text { Missing }\end{array}$ & $\begin{array}{l}3262(69.7) \\
1099(23.5) \\
127(2.7) \\
192(4.1)\end{array}$ & $\begin{array}{l}1264(26.0) \\
2563(52.7) \\
875(18.0) \\
161(3.3)\end{array}$ & $<0.001$ & $\begin{array}{l}1070(49.0) \\
997(45.7) \\
117(5.4) \\
0(0)\end{array}$ & $\begin{array}{l}1007(50.7) \\
934(42.8) \\
143(6.5) \\
0(0)\end{array}$ & 0.071 \\
\hline $\begin{array}{l}\text { PgR-status } \\
\text { Negative } \\
\text { Positive } \\
\text { Missing }\end{array}$ & $\begin{array}{l}681(14.6) \\
3970(84.8) \\
29(0.6)\end{array}$ & $\begin{array}{l}1011(20.8) \\
3808(78.3) \\
44(0.9)\end{array}$ & $<0.001$ & $\begin{array}{l}416(19.0) \\
1768(81.0) \\
0(0)\end{array}$ & $\begin{array}{l}403(18.5) \\
1781(81.5) \\
0(0)\end{array}$ & 0.614 \\
\hline $\begin{array}{l}\text { Grade } \\
\text { I } \\
\text { II } \\
\text { III } \\
\text { Missing }\end{array}$ & $\begin{array}{l}1395(29.8) \\
2414(51.6) \\
332(7.1) \\
539(11.5)\end{array}$ & $\begin{array}{l}658(13.5) \\
2309(47.5) \\
1158(23.8) \\
738(15.2)\end{array}$ & $<0.001$ & NA & NA & NA \\
\hline $\begin{array}{l}\text { CCI } \\
0 \\
1 \\
2 \\
3+\end{array}$ & $\begin{array}{l}3959(84.6) \\
373(8.0) \\
244(5.2) \\
104(2.2)\end{array}$ & $\begin{array}{l}3916(80.5) \\
483(9.9) \\
295(6.1) \\
169(3.5)\end{array}$ & $<0.001$ & $\begin{array}{l}1707(78.2) \\
247(11.3) \\
151(6.9) \\
79(3.6)\end{array}$ & $\begin{array}{l}1799(82.4) \\
201(9.2) \\
119(5.4) \\
65(3.0)\end{array}$ & 0.006 \\
\hline $\begin{array}{l}\text { Chemotherapy } \\
\text { No } \\
\text { Yes }\end{array}$ & $\begin{array}{l}4220(90.2) \\
460(9.8)\end{array}$ & $\begin{array}{l}2924(60.1) \\
1939(39.9)\end{array}$ & $<0.001$ & $\begin{array}{l}1751(80.2) \\
433(19.8)\end{array}$ & $\begin{array}{l}1711(78.3) \\
473(21.7)\end{array}$ & 0.136 \\
\hline $\begin{array}{l}\text { Radiotherapy } \\
\text { No } \\
\text { Yes } \\
\text { Missing }\end{array}$ & $\begin{array}{l}1227(26.2) \\
3276(70.0) \\
177(3.8)\end{array}$ & $\begin{array}{l}1006(22.7) \\
3531(72.6) \\
226(4.6)\end{array}$ & $<0.001$ & $\begin{array}{l}736(33.7) \\
1448(66.3) \\
0(0)\end{array}$ & $\begin{array}{l}567(26.0) \\
1617(74.0) \\
0(0)\end{array}$ & $<0.001$ \\
\hline $\begin{array}{l}\text { Educational level } \\
\text { Low } \\
\text { Middle } \\
\text { High } \\
\text { Missing }\end{array}$ & $\begin{array}{l}1310(28.0) \\
1842(39.4) \\
1485(31.7) \\
43(0.9)\end{array}$ & $\begin{array}{l}1440(29.6) \\
1913(39.3) \\
1454(29.9) \\
56(1.2)\end{array}$ & 0.111 & $\begin{array}{l}632(28.9) \\
866(39.7) \\
686(31.4) \\
0(0)\end{array}$ & $\begin{array}{l}650(29.8) \\
858(39.3) \\
676(31.0) \\
0(0)\end{array}$ & 0.834 \\
\hline $\begin{array}{l}\text { Civil-status } \\
\text { Single } \\
\text { Married } \\
\text { Divorced } \\
\text { Widow } \\
\text { Missing }\end{array}$ & $\begin{array}{l}577(12.3) \\
2369(50.3) \\
939(20.1) \\
795(19.0) \\
0(0)\end{array}$ & $\begin{array}{l}579(11.7) \\
2471(50.8) \\
956(19.7) \\
851(17.5) \\
6(0.1)\end{array}$ & 0.152 & $\begin{array}{l}273(12.5) \\
1068(48.9) \\
438(20.1) \\
405(18.5) \\
0(0)\end{array}$ & $\begin{array}{l}267(12.2) \\
1113(51.0) \\
462(21.2) \\
342(15.7) \\
0(0)\end{array}$ & 0.174 \\
\hline
\end{tabular}


Table 1 (continued)

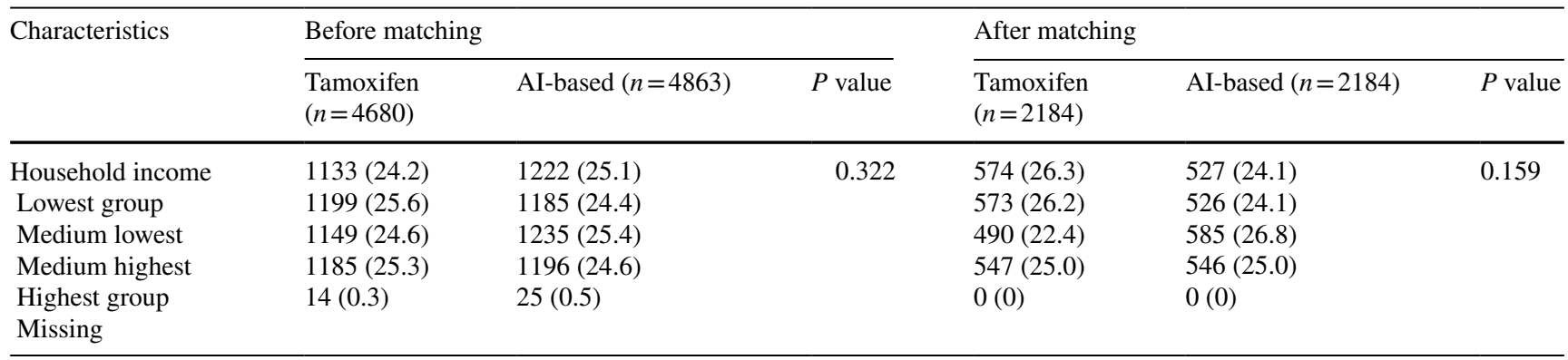

In the HER2-positive cohort, AI-based ET was not associated with improved OS compared to TAM, neither in the univariate (HR: 0.50; 95\% CI: 0.10-2.60, $p=0.413$; Fig. 3b) nor in the multivariate Cox regression analysis (HR: 0.62; 95\% CI: $0.11-3.38, p=0.345)$.

\section{Discussion}

In our study cohort of BC patients treated according to modern strategies, we found that AI-based therapy improves BCSS in the HER2-negative BC cohort. Although HR in the HER2-positive BC cohort is in the same direction as in HER2-negative BC cohort, the magnitude of effect seems to be larger for the HER2-negative cohort. Whether the nonstatistically significant results for HER2-positive BC cohort is due to few events or a small and probably clinical nonsignificant impact of AI-based ET in HER2-positive disease remains to be answered.

Optimizing treatment strategies for $\mathrm{HR}+/ \mathrm{HER} 2+\mathrm{BC}$ in postmenopausal women is an ongoing challenge in the modern era of HER2-directed therapy. Adjuvant trastuzumab, in conjunction with chemotherapy, is the standard of care for patients with HER2-positive disease [5]. The use of ET in this patient group is an important treatment approach but the increased risk for resistance to ET due to the crosstalk between HR and HER2 pathways poses challenges on which treatment approach that target both of these pathways is better in improving survival in this patient group [9, 10, 12].

In the present study, we investigated whether the benefit of AIs compared to TAM as adjuvant therapy in postmenopausal BC patients differed by HER2-status. Our study cohort reflects the current clinical practice in a real-world setting in Sweden where patients with HER2-positive BC received treatment in accordance to current clinical practice, i.e., modern HER2-directed therapy combined with ET.

In the HER2-negative cohort, we found a BCSS benefit in patients treated with AI-based therapy compared to TAM. Moreover, a trend for OS improvement was observed. This finding was expected considering evidence from randomized trials and meta-analyses about the efficacy of AI compared to TAM in HR+/HER2 - BC patients [2-4].

In the HER2-positive cohort, we observed a similar trend regarding the benefit of AI-based ET compared to TAM but the findings were not statistically significant. These findings are consistent with the results published by Darkus et al. [14] where postmenopausal patients with early-stage $\mathrm{HR}+/ \mathrm{HER} 2$ + BC seemed to experience a small; however, non-significant benefit from AI. Bartlett et al. [13] however found an opposite trend in favor of TAM in patients with HR+/HER2+ disease in their meta-analysis. The results of the EBCTCG meta-analysis showed that the rate ratios for improvement of OS in favor of AIs range between 0.84 and 0.89 in postmenopausal women [13]. Our results indicate a larger magnitude of benefit for AIs compared to TAM for OS. Although the magnitude of benefit seemed to be larger in our study results than in EBCTCG meta-analysis, this could be explained by the total number of events and the sample size in our cohort compared to the meta-analysis. In fact, our sample size was considerably smaller with one third of patients in the HER2-negative cohort and a fifth of patients in the HER2-positive cohort compared to the EBCTCG one. Moreover, a low number of events was captured in our study cohort due to the relatively short median follow-up. The substantial differences on the treatment approaches regarding HER2-directed therapy between the current study and the previous ones can partially explain the different results. All patients with HER2-positive disease in 
Table 2 Patient-, tumor and treatment characteristics in unmatched and propensity-matched patients with HER2-positive breast cancer

\begin{tabular}{|c|c|c|c|c|c|c|}
\hline \multirow[t]{2}{*}{ Characteristics } & \multicolumn{3}{|l|}{ Before matching } & \multicolumn{3}{|l|}{ After matching } \\
\hline & Tamoxifen $(n=124)$ & AI-based $(n=558)$ & $P$ value & Tamoxifen $(n=107)$ & AI-based $(n=107)$ & $P$ value \\
\hline $\begin{array}{l}\text { Age } \\
\leq 60 \\
61-65 \\
66-70 \\
71-75 \\
>75\end{array}$ & $\begin{array}{l}67(54.0) \\
26(21.0) \\
13(10.5) \\
13(10.5) \\
5(4.0)\end{array}$ & $\begin{array}{l}191(34.2) \\
138(24.7) \\
131(23.5) \\
72(12.9) \\
26(4.7)\end{array}$ & 0.001 & $\begin{array}{l}57(53.3) \\
25(23.4) \\
12(11.2) \\
9(8.4) \\
4(3.7)\end{array}$ & $\begin{array}{l}58(54.2) \\
23(21.5) \\
12(11.2) \\
11(1.03) \\
3(2.8)\end{array}$ & 0.980 \\
\hline $\begin{array}{l}\text { Detection method } \\
\text { Screening } \\
\text { Clinically detected } \\
\text { Missing }\end{array}$ & $\begin{array}{l}72(58.1) \\
31(25.0) \\
21(16.9)\end{array}$ & $\begin{array}{l}278(49.8) \\
144(25.8) \\
136(24.4)\end{array}$ & 0.437 & NA & NA & \\
\hline $\begin{array}{l}\text { Type of surgery } \\
\text { Breast conserving } \\
\text { Mastectomy }\end{array}$ & $\begin{array}{l}79(63.7) \\
45(36.3)\end{array}$ & $\begin{array}{l}271(48.6) \\
287(51.4)\end{array}$ & 0.002 & $\begin{array}{l}34(31.8) \\
73(68.2)\end{array}$ & $\begin{array}{l}32(29.9) \\
75(70.1)\end{array}$ & 0.767 \\
\hline $\begin{array}{l}\text { Histology } \\
\text { Ductal or mixed } \\
\text { Lobular } \\
\text { Other } \\
\text { Missing }\end{array}$ & $\begin{array}{l}113(91.1) \\
5(4.0) \\
2(1.6) \\
4(3.2)\end{array}$ & $\begin{array}{l}520(93.2) \\
22(3.9) \\
3(0.5) \\
13(2.3)\end{array}$ & 0.438 & $\begin{array}{l}101(94.4) \\
1(0.9) \\
5(4.7) \\
0(0)\end{array}$ & $\begin{array}{l}104(97.2) \\
1(0.9) \\
2(1.9) \\
0(0)\end{array}$ & 0.851 \\
\hline $\begin{array}{l}\text { Stage } \\
\text { I } \\
\text { II } \\
\text { III } \\
\text { Missing }\end{array}$ & $\begin{array}{l}58(46.8) \\
58(46.8) \\
7(5.6) \\
1(0.8)\end{array}$ & $\begin{array}{l}195(34.9) \\
251(45.0) \\
97(17.4) \\
15(2.7)\end{array}$ & 0.002 & $\begin{array}{l}51(47.7) \\
41(45.8) \\
7(6.5) \\
0(0)\end{array}$ & $\begin{array}{l}54(50.5) \\
45(42.1) \\
8(7.5) \\
0(0)\end{array}$ & 0.851 \\
\hline $\begin{array}{l}\text { PgR-status } \\
\text { Negative } \\
\text { Positive } \\
\text { Missing }\end{array}$ & $\begin{array}{l}52(41.9) \\
67(54.0) \\
5(4.0)\end{array}$ & $\begin{array}{l}319(57.2) \\
226(40.5) \\
13(2.3)\end{array}$ & 0.655 & $\begin{array}{l}48(44.9) \\
59(55.1) \\
0(0)\end{array}$ & $\begin{array}{l}46(43.0) \\
61(57.0) \\
0(0)\end{array}$ & 0.783 \\
\hline $\begin{array}{l}\text { Grade } \\
\text { I } \\
\text { II } \\
\text { III } \\
\text { Missing }\end{array}$ & $\begin{array}{l}4(3.2) \\
38(30.6) \\
57(46.0) \\
25(20.2)\end{array}$ & $\begin{array}{l}15(2.7) \\
192(34.3) \\
261(46.8) \\
90(16.1)\end{array}$ & 0.836 & NA & NA & \\
\hline $\begin{array}{l}\text { CCI } \\
0 \\
1 \\
2 \\
3+\end{array}$ & $\begin{array}{l}110(88.7) \\
8(6.5) \\
5(4.0) \\
1(0.8)\end{array}$ & $\begin{array}{l}487(87.3) \\
40(7.2) \\
24(4.3) \\
7(1.3)\end{array}$ & 0.962 & $\begin{array}{l}93(86.9) \\
8(7.5) \\
5(4.7) \\
1(0.9)\end{array}$ & $\begin{array}{l}96(89.7) \\
4(3.7) \\
4(3.7) \\
3(2.8)\end{array}$ & 0.477 \\
\hline $\begin{array}{l}\text { Chemotherapy } \\
\text { No } \\
\text { Yes }\end{array}$ & $\begin{array}{l}0(0) \\
124(100)\end{array}$ & $\begin{array}{l}0(0) \\
558(100)\end{array}$ & $\mathrm{NC}$ & $\begin{array}{l}0(0) \\
107(100)\end{array}$ & $\begin{array}{l}0(0) \\
107(100)\end{array}$ & $\mathrm{NC}$ \\
\hline $\begin{array}{l}\text { Radiotherapy } \\
\text { No } \\
\text { Yes } \\
\text { Missing }\end{array}$ & $\begin{array}{l}16(12.9) \\
102(82.3) \\
6(4.8)\end{array}$ & $\begin{array}{l}97(17.4) \\
447(80.1) \\
14(2.5)\end{array}$ & 0.264 & $\begin{array}{l}16(15.0) \\
91(85.0) \\
0(0)\end{array}$ & $\begin{array}{l}16(15.0) \\
91(85.0) \\
0(0)\end{array}$ & 1.000 \\
\hline $\begin{array}{l}\text { Educational level } \\
\text { Low } \\
\text { Middle } \\
\text { High } \\
\text { Missing }\end{array}$ & $\begin{array}{l}25(20.2) \\
61(49.2) \\
38(30.6) \\
0(0)\end{array}$ & $\begin{array}{l}129(23.1) \\
254(45.5) \\
172(30.8) \\
3(0.5)\end{array}$ & 0.710 & $\begin{array}{l}25(23.4) \\
49(45.8) \\
33(30.8) \\
0(0)\end{array}$ & $\begin{array}{l}24(22.4) \\
48(44.9) \\
35(32.7) \\
0(0)\end{array}$ & 0.956 \\
\hline $\begin{array}{l}\text { Civil-status } \\
\text { Single } \\
\text { Married } \\
\text { Divorced } \\
\text { Widow }\end{array}$ & $\begin{array}{l}30(24.2) \\
63(50.8) \\
17(13.7) \\
14(11.3)\end{array}$ & $\begin{array}{l}75(13.4) \\
309(55.4) \\
118(21.1) \\
56(10.0)\end{array}$ & 0.112 & $\begin{array}{l}23(21.5) \\
53(49.5) \\
17(15.9) \\
14(13.1)\end{array}$ & $\begin{array}{l}16(15.0) \\
59(55.1) \\
22(20.6) \\
10(9.3)\end{array}$ & 0.410 \\
\hline
\end{tabular}


Table 2 (continued)

\begin{tabular}{|c|c|c|c|c|c|c|}
\hline \multirow[t]{2}{*}{ Characteristics } & \multicolumn{3}{|l|}{ Before matching } & \multicolumn{3}{|l|}{ After matching } \\
\hline & Tamoxifen $(n=124)$ & AI-based $(n=558)$ & $P$ value & Tamoxifen $(n=107)$ & AI-based $(n=107)$ & $P$ value \\
\hline Household income & $15(12.1)$ & $92(16.5)$ & 0.610 & $15(14.0)$ & $16(15.0)$ & 0.894 \\
\hline Lowest group & $33(26.6)$ & $130(23.3)$ & & $25(23.4)$ & $26(24.3)$ & \\
\hline Medium lowest & $35(28.2)$ & $162(29.0)$ & & $31(29.0)$ & $26(24.3)$ & \\
\hline Medium highest & $40(32.3)$ & $171(30.6)$ & & $36(33.6)$ & $39(36.4)$ & \\
\hline Highest group & $1(0.8)$ & $3(0.5)$ & & $0(0)$ & $0(0)$ & \\
\hline
\end{tabular}

our study cohort received treatment with HER2-blockade, whereas in the ECBTCG- meta-analysis and in Bartlett et al. meta-analysis the majority of the patients received no HER2-blockade and in the Darcus et al. study cohort only two-thirds of patients received HER2-blockade.

In the multivariate analyses we found a larger magnitude of benefit for OS compared to the benefit on BCSS for the HER2-negative cohort. Although one could argue that this difference in magnitude seems to be paradoxical since the non-BC mortality is not expected to be reduced by ET and the risk for potentially ET-related toxicity is always present, this larger magnitude for OS should be considered a consequence of the few events in our cohort rather than a true difference in BCSS and OS benefits.

Our study has several limitations that needs to be considered when interpreting the results. First, type of ET was offered on selected grounds. AI-based therapy tended to be the treatment of choice in more advanced disease. Although this bias could be mitigated through PSM, the comparison between AI and TAM might still be influenced by differences in baseline characteristics. Moreover, we divided the patients into the treatment groups based on the planned treatment and not the actual treatment based on adherence. However, the adherence in Sweden is relatively good without any significant differences in adherence rates between AI and Tam and, thus the potential impact of this limitation to the results is expected to be low [15]. In addition, the sample size in the HR+/HER2 + BC cohort was relatively small, especially after PSM, thus jeopardizing the precision of the estimates. Furthermore, the median follow-up for the study cohort was relatively short resulting in a relatively low number of events. As a result, our findings can be considered valid regarding the first years after BC diagnosis but should not be applied in terms of late recurrence events.

In summary, our results do not support the hypothesis that HER2-status has a predictive value for ET in postmenopausal BC patients. AI-based ET remains the treatment of choice for postmenopausal BC patients in both HER2-negative and HER2-positive disease. Large-scale studies with longer follow-up would further enhance the evidence on the optimal ET strategy in HR+/HER2 + BC patients. 
Fig. 2 a Kaplan-Meier for breast cancer-specific survival in the HER2-negative cohort by type of endocrine therapy. b Kaplan-Meier for breast cancer-specific survival in the HER2-positive cohort by type of endocrine therapy. Gray line is AI-based therapy, whereas black line is Tamoxifen
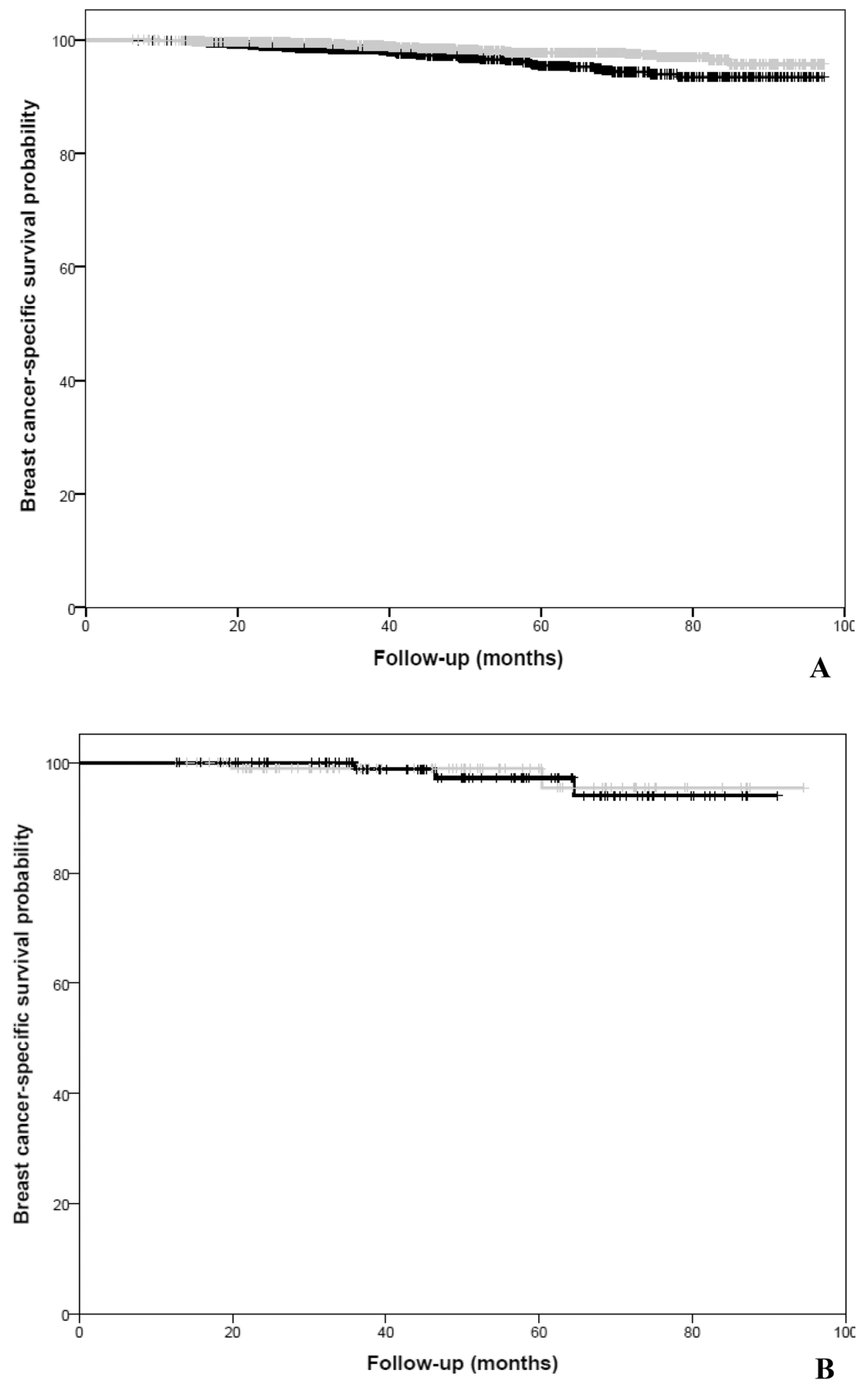
Fig. 3 a Kaplan-Meier for overall survival in the HER2negative cohort by type of endocrine therapy. b KaplanMeier for overall survival in the HER2-positive cohort by type of endocrine therapy. Gray line is AI-based therapy, whereas black line is Tamoxifen.
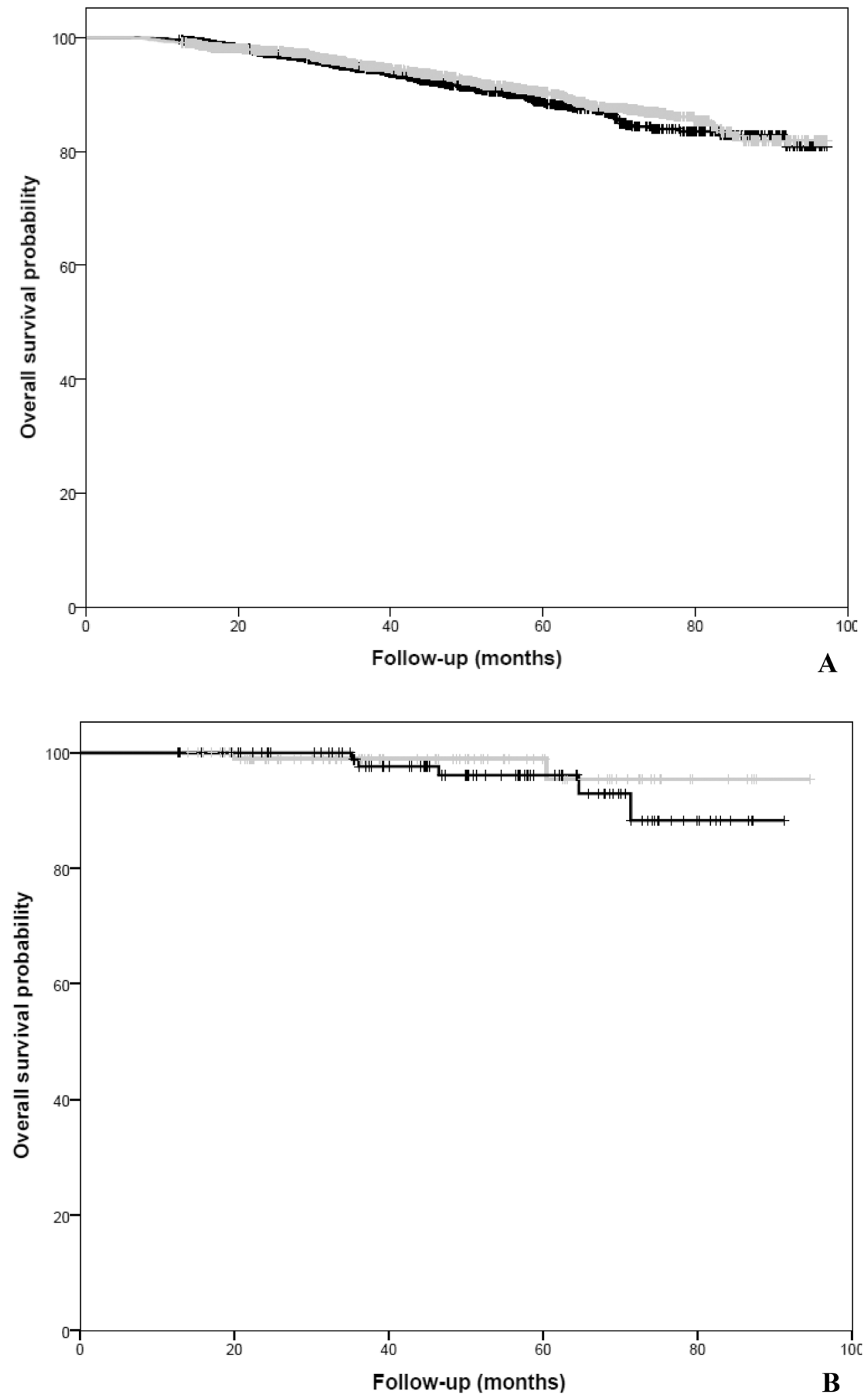
Funding Open access funding provided by Uppsala University.

\section{Compliance with ethical standards}

The study was conducted without support from any funding source. The authors have no conflict of interest to declare. The study was approved by the Regional Ethical Committee Uppsala.

Open Access This article is licensed under a Creative Commons Attribution 4.0 International License, which permits use, sharing, adaptation, distribution and reproduction in any medium or format, as long as you give appropriate credit to the original author(s) and the source, provide a link to the Creative Commons licence, and indicate if changes were made. The images or other third party material in this article are included in the article's Creative Commons licence, unless indicated otherwise in a credit line to the material. If material is not included in the article's Creative Commons licence and your intended use is not permitted by statutory regulation or exceeds the permitted use, you will need to obtain permission directly from the copyright holder. To view a copy of this licence, visit http://creativecommons.org/licenses/by/4.0/.

\section{References}

1. Noone AM, Cronin KA, Altekruse SF, Howlader N, Lewis DR, Petkov VI, Penberthy L (2017) Cancer incidence and survival trends by subtype using data from the surveillance epidemiology and end results program, 1992-2013. Cancer Epidemiol Biomarkers Prev 26(4):632-641

2. Forbes JF, Cuzick J, Buzdar A, Howell A, Tobias JS, Baum M (2008) Effect of anastrozole and tamoxifen as adjuvant treatment for early-stage breast cancer: 100-month analysis of the ATAC trial. Lancet Oncol 9(1):45-53

3. Breast International Group 1-98 Collaborative G, Thurlimann B, Keshaviah A, Coates AS, Mouridsen H, Mauriac L, Forbes JF, Paridaens R, Castiglione-Gertsch M, Gelber RD et al (2005) A comparison of letrozole and tamoxifen in postmenopausal women with early breast cancer. N Engl J Med 353(26):2747-2757

4. Early Breast Cancer Trialists' Collaborative G (2015) Aromatase inhibitors versus tamoxifen in early breast cancer: patient-level meta-analysis of the randomised trials. Lancet 386(10001):1341-1352

5. Slamon D, Eiermann W, Robert N, Pienkowski T, Martin M, Press M, Mackey J, Glaspy J, Chan A, Pawlicki M et al (2011) Adjuvant trastuzumab in HER2-positive breast cancer. N Engl J Med 365(14):1273-1283

6. Early Breast Cancer Trialists' Collaborative G (2018) Long-term outcomes for neoadjuvant versus adjuvant chemotherapy in early breast cancer: meta-analysis of individual patient data from ten randomised trials. Lancet Oncol 19(1):27-39
7. Chen Z, Wang Y, Warden C, Chen S (2015) Cross-talk between ER and HER2 regulates c-MYC-mediated glutamine metabolism in aromatase inhibitor resistant breast cancer cells. J Steroid Biochem Mol Biol 149:118-127

8. Shou J, Massarweh S, Osborne CK, Wakeling AE, Ali S, Weiss $\mathrm{H}$, Schiff R (2004) Mechanisms of tamoxifen resistance: increased estrogen receptor-HER2/neu cross-talk in ER/HER2-positive breast cancer. J Natl Cancer Inst 96(12):926-935

9. De Laurentiis M, Arpino G, Massarelli E, Ruggiero A, Carlomagno C, Ciardiello F, Tortora G, D'Agostino D, Caputo $\mathrm{F}$, Cancello $\mathrm{G}$ et al (2005) A meta-analysis on the interaction between HER-2 expression and response to endocrine treatment in advanced breast cancer. Clin Cancer Res 11(13):4741-4748

10. De Placido S, De Laurentiis M, Carlomagno C, Gallo C, Perrone F, Pepe S, Ruggiero A, Marinelli A, Pagliarulo C, Panico L et al (2003) Twenty-year results of the Naples GUN randomized trial: predictive factors of adjuvant tamoxifen efficacy in early breast cancer. Clin Cancer Res 9(3):1039-1046

11. Dowsett M, Allred C, Knox J, Quinn E, Salter J, Wale C, Cuzick J, Houghton J, Williams N, Mallon E et al (2008) Relationship between quantitative estrogen and progesterone receptor expression and human epidermal growth factor receptor 2 (HER-2) status with recurrence in the Arimidex, Tamoxifen, Alone or in Combination trial. J Clin Oncol 26(7):1059-1065

12. Ellis MJ, Coop A, Singh B, Mauriac L, Llombert-Cussac A, Janicke F, Miller WR, Evans DB, Dugan M, Brady C et al (2001) Letrozole is more effective neoadjuvant endocrine therapy than tamoxifen for ErbB-1- and/or ErbB-2-positive, estrogen receptorpositive primary breast cancer: evidence from a phase III randomized trial. J Clin Oncol 19(18):3808-3816

13. Bartlett JMS, Ahmed I, Regan MM, Sestak I, Mallon EA, Dell'Orto P, Thurlimann B, Seynaeve C, Putter H, Van de Velde CJH et al (2017) HER2 status predicts for upfront AI benefit: a TRANS-AIOG meta-analysis of 12,129 patients from ATAC, BIG 1-98 and TEAM with centrally determined HER2. Eur J Cancer 79:129-138

14. Dackus G, Jozwiak K, Sonke GS, van der Wall E, van Diest PJ, Hauptmann M, Siesling S, Linn SC (2018) Optimal adjuvant endocrine treatment of ER+/HER2+ breast cancer patients by age at diagnosis: a population-based cohort study. Eur J Cancer 90:92-101

15. Andersson A, Von Wechenfeldt Väppling A, De Jong A, Nyström L (2019) Adherence to adjuvant endocrine therapy after breast cancer in Sweden 2008-2010: a nationwide survey. J Clin Oncol $37: 523-523$

Publisher's Note Springer Nature remains neutral with regard to jurisdictional claims in published maps and institutional affiliations. 